\title{
PENGARUH MARGIN LABA KOTOR DAN MARGIN LABA OPERASIONAL TERHADAP PERTUMBUHAN PENDAPATAN PADA PT. ACE HARDWARE INDONESIA, TBK.
}

\author{
Roudhatul Jannah \\ Manajemen Keuangan Syariah, UIN Sunan Gunung Djati Bandung \\ roudhatulj99@gmail.com \\ Dadang Husen Sobana \\ Manajemen Keuangan Syariah, UIN Sunan Gunung Djati Bandung \\ dadanghusensobana@uinsgd.ac.id \\ Sulaeman Jajuli \\ Ekonomi Syariah, UIN Sultan Maulana Hasanudin Banten \\ jaka_jajuli@yahoo.com
}

\begin{abstract}
This article is motivated by the assumption of stable income growth indicating the efficiency of the company in managing its operating activities, and its human resources to increase profitability. This article aims to determine whether the gross profit margin and operating profit margin are factors that affect revenue growth at PT. ACE Hardware Indonesia, Tbk. This article also uses descriptive methods and quantitative approaches. Research data is secondary data taken from the financial statements of PT. ACE Hardware Indonesia, Tbk. and supported by literature study and documentation, which were processed statistically and quantitatively using SPSS. The results of this study conclude that both partially and simultaneously, the gross profit margin and the operating profit margin do not have a significant effect on the growth of PT. ACE Hardware Indonesia, Tbk. The implication of this research is that companies must pay attention to other factors to increase revenue growth, besides that the company must control operating expenses as well as cost of goods sold in order to maximize the increase in operating profit margins and gross profit margins.
\end{abstract}

Keywords: Gross Profit Margin, Operating Profit Margin, Income Growth

\begin{abstract}
Abstrak
Artikel ini dilatarbelakangi oleh asumsi pertumbuhan pendapatan yang stabil mengindikasikan efisiensi perusahaan dalam mengelola kegiatan operasi, dan sumber daya manusianya untuk meningkatkan profitabilitas. Artikel ini bertujuan untuk mengetahui apakah margin laba kotor dan margin laba operasional menjadi faktor yang mempengaruhi pertumbuhan pendapatan pada PT. ACE Hardware Indonesia, Tbk. Artikel ini juga menggunakan metode deskriptif dan pendekatan kuantitatif. Data penelitian merupakan data sekunder yang diambil dari laporan keuangan PT. ACE Hardware Indonesia, Tbk. dan didukung dengan studi kepustakaan dan dokumentasi, yang diolah secara statistik dan kuantitatif menggunakan SPSS. Hasil penelitian ini menyimpulkan baik secara parsial dan simultan, margin laba kotor dan margin laba operasional tidak memiliki pengaruh yang signifikan terhadap pertumbuhan pendapatan PT. ACE Hardware Indonesia, Tbk. Implikasi dari penelitian ini adalah perusahaan harus memperhatikan faktor lain untuk meningkatkan pertumbuhan pendapatan, selain itu juga perusahaan harus mengontrol beban-beban operasional juga beban pokok penjualan agar maksimal menaikkan margin laba operasional dan margin laba kotor.
\end{abstract}

Kata kunci: Margin Laba Kotor, Margin Laba Operasional, Pertumbuhan Pendapatan 


\section{Pendahuluan}

Sebagai salah satu entitas bisnis yang menjalankan kegiatan produksi mulai dari mengolah bahan mentah hingga barang jadi untuk menyediakan kebutuhan masyarakat baik barang ataupun jasa, maka perusahaan akan bersaing dalam memperoleh keuntungan yang maksimal denga budget yang minimal. Oleh karena itu, untuk menjaga keseimbangan operasionalnya perusahaan akan menyusun strategi perusahaan untuk menekan expense, sehingga berdampak pada laba kotor dan laba operasional yang tinggi dan kemudian menaikkan income.

Untuk mencapai tujuan perusahaan tersebut, sumber daya manusia yang ada di dalamnya harus memiliki tingkat efektivitas yang tinggi. Hal itu dapat dilihat dari peningkatan pendapatan yang stabil pada perusahaan setiap tahunnya. Pendapatan atau income adalah summary atas hasil neto dari aktivitas operasional usaha pada satu periode tertentu yang dinyatakan dalam istilah finance (Subramanyam \& Wild, 2012).

Pendapatan yang terus bertumbuh atau income growth dapat dilihat dari peningkatan laba setiap periode yang dinyatakan dalam persentase. Dikatakan mengalami pertumbuhan apabila selisih antara periode sekarang dengan periode tahun sebelumnya adalah positif. Implikasinya, ketika income growth meningkat akan menjadi respon positif bagi pasar modal karena harga saham naik dan berdampak pada return saham (Gunawan \& Wahyuni, 2013). Selain itu, income growth yang tinggi akan memberikan keluasaan dalam pengelolaan kebijakan operasional. Agar menjaga kestabilan pertumbuhan pendapatan tentu ada faktor keuangan operasional yang mempengaruhinya, peneliti memfokuskan pada margin laba kotor dan margin laba operasional.

Penelitian ini memfokuskan penelitian pada PT. ACE Hardware Indonesia, Tbk, karena pada laporan keuangannya tercatat net income yang cenderung meningkat secara stabil setiap tahunnya. Berikut data laporan keuangan terkait penelitian ini:

\section{Tabel 1 Data Penelitian}

Data dalam persen $(\%)$

\begin{tabular}{|c|c|c|c|}
\hline Tahun & Margin Laba Kotor & Margin Laba Operasional & Pertumbuhan Pendapatan \\
\hline 2009 & 40,91 & 13,20 & 18,22 \\
\hline 2010 & 43,51 & 13,38 & 15,16 \\
\hline 2011 & 46,86 & 15,97 & 57,16 \\
\hline 2012 & 48,59 & 17,61 & 53,43 \\
\hline 2013 & 50,22 & 16,91 & 17,29 \\
\hline 2014 & 48,83 & 15,95 & 9,12 \\
\hline 2015 & 48,00 & 16,38 & 6,56 \\
\hline 2016 & 48,15 & 18,03 & 20,74 \\
\hline 2017 & 48,23 & 16,51 & 10,56 \\
\hline 2018 & 48,33 & 17,25 & 25,05 \\
\hline \multicolumn{2}{|c|}{ Sumber: Laporan Publikasi Keuangan PT. ACE Hardware Indonesia, Tbk. } \\
\hline
\end{tabular}

Data di atas merupakan tampilan variabel dalam penelitian ini. Margin laba kotor merupakan rasio yang penghitungannya membandingkan laba kotor dengan penjualan bersih perusahaan. Melalui rasio ini dapat dilihat keuntungan yang diperoleh dari harga penjualan setiap produk. Apabila margin laba kotor meningkat, maka itu menunjukkan tingkat pengembalian kotor dari penjualan berish semakin tinggi, sehingga pertumbuhan pendapatan yang didapatkan juga semakin meningkat, dan seperti itu juga sebaliknya (Samsul, 2015). Sedangkan margin laba operasional, merupakan rasio keuangan yang digunakan untuk melihat 
sejauh mana efektivitas operasional perusahaan, yang dihitung dari pembagian laba operasi dan penjualan. Teorinya, apabila rasio ini meningkatkan maka menunjukkan perusahaan semakin efisien mengelola operasionalnya dan berimplikasi pada pertumbuhan pendapatan (Syamsuddin, 2010).

Pada data di atas dapat dilihat PT. ACE Hardware Indonesia, Tbk. terdapat beberapa masalah, pada tahun 2013 secara parsial margin laba bersih mengalami peningkatan namun tidak diikuti oleh peningkatan pertumbuhan pendapatan, kemudian tahun 2015 secara parsial margin laba operasional mengalami penurunan namun penahanan kas justru meningkat. Lalu, tahun 2010 secara simultan, margin laba kotor dan margin laba operasional mengalami peningkatan, namun pertumbuhan pendapatan justru mengalami penurunan yang signfikan. Merujuk pada permasalahan di atas maka dipandang perlu melakukan penelitian terhadap PT. ACE Hardware Indonesia, Tbk.

\section{Metode}

Artikel ini menggunakan metode deskriptif dan pendekatan kuantitatif karena bentuk penelitian yang digunakan juga penelitian kuantitatif. Berpengaruh atau tidaknya suatu penelitian ini dibuktikan dengan berbagai metode analisis yaitu uji kuantitatif dengan bantuan SPSS, teknik penghitungan yang digunakan adalah analisis regresi, uji hipotesis, dan uji R Square dan Pearson Product Moment. Data yang diolah didapatkan dari laporan tahunan PT. ACE Hardware Indonesia, Tbk. yang dilansir dari laman resmi perusahaan. Data dalam penelitian ini diperoleh melalui studi kepustakaan, dan dokumentasi. (Sugiyono, 2013).

\section{Hasil dan Pembahasan}

\subsection{Pengaruh Margin Laba Kotor terhadap Pertumbuhan Pendapatan}

Margin Laba Kotor adalah bagian dari rasip profitabilitas. Laba kotor ini digunakan untuk mengetahui efisiensi perusahaan dalam menggunakan sumber daya nya dalam kegiatan produksi dan menjual produk tersebut guna mencapai keuntungan (Darsono \& Ashari, 2005). Peningkatan atau menurunan rasio laba kotor ini mengindikasikan tingkat laba kotor yang dimiliki oleh perusahaan dari penjualan bersihnya. Apabila meningkat maka pertumbuhan pendapatan akan naik, dan apabila menurun Pertumbuhan Pendapatan juga akan turun. Perusahaan dapat mengendalikan margin laba kotornya dengan menekan biaya pokok produksi, atau biaya pokok penjualan.

Penelitian ini ternyata tidak menjawab atau konsisten dengan teori di atas, berikut hasil penelitian yang telah di lakukan:

Tabel 1 Hasil Uji Regresi Linear dan Uji t Pengaruh Margin Laba Kotor terhadap Pertumbuhan Pendapatan

\begin{tabular}{|c|c|c|c|c|c|c|}
\hline \multicolumn{7}{|c|}{ Coefficients $^{a}$} \\
\hline & \multirow[t]{2}{*}{ Model } & \multicolumn{2}{|c|}{$\begin{array}{l}\text { Unstandardized } \\
\text { Coefficients }\end{array}$} & $\begin{array}{c}\text { Standardized } \\
\text { Coefficients }\end{array}$ & \multirow[t]{2}{*}{$\mathrm{t}$} & \multirow[t]{2}{*}{ Sig. } \\
\hline & & $\mathrm{B}$ & Std. Error & Beta & & \\
\hline & (Constant) & 7.267 & 105.490 & & .069 & .947 \\
\hline 1 & $\begin{array}{c}\text { Margin Laba } \\
\text { Kotor }\end{array}$ & .341 & 2.233 & .054 & .153 & .883 \\
\hline
\end{tabular}

a. Dependent Variable: Pertumbuhan Pendapatan

Sumber: output SPSS versi 20 
Berdasarkan hasil pengolahan data menggunakan SPSS for Windows Version 23, maka diperoleh persamaan regresi sebagai berikut.

\section{Pertumbuhan Pendapatan $=7,267+0,341$ (Margin Laba Kotor)}

Nilai constanta pada hasil penelitian ini adalah 7,267, dan koefisien regresi adalah 0,341. Angka ini mengindikasikan, apabila margin laba kotor diabaikan atau bernilai 0, maka nilai pertumbuhan pendapatan adalah 7,267. Kemudian, apabila margin laba kotor mengalami perubahan yaitu peningkatan sebesar satu satuan atau 1\% maka, pertumbuhan pendapatan akan mengalami kenaikan sebesar 0,341.

Pengaruh Margin Laba Kotor terhadap Penahanan Kas dapat dilihat dari hasil uji $t$ dimana hasil di atas tidak memenuhi kriteria berpengaruh karena 0,153<2,306 dengan Sig. 0,883 > 0,05. Sehingga peneliti mendapatkan hasil akhir bahwa Margin Laba Kotor tidak memiliki pengaruh terhadap Pertumbuhan Pendapatan PT. ACE Hardware Indonesia, Tbk. periode 2009-2018.

Selanjutnya kekuatan hubungan dan kontribusi pengaruh Margin Laba Kotor terhadap Penahanan Kas dapat dilihat pada tabel berikut:

Tabel 2 Hasil Uji Korelasi dan Koefisien Determinasi

\begin{tabular}{|l|c|c|r|r|}
\hline \multicolumn{5}{|c|}{ Model Summary } \\
\hline Model & $\mathrm{R}$ & R Square & Adjusted R Square & Std. Error of the Estimate \\
\hline 1 & $.054 \mathrm{a}$ & .003 & -.122 & 18.79993 \\
\hline a. Predictors: (Constant), Margin Laba Kotor & \\
\hline
\end{tabular}

Sumber: hasil output SPSS versi 20

Berdasarkan perhitungan di atas dapat diketahui besarnya hubungan Margin Laba Kotor terhadap Pertumbuhan Pendapatan adalah 0,054, artinya korelasi tersebut sangat lemah. Dan R Square $\left(\mathrm{r}^{2}\right)$ 0,003 atau sama dengan 0,3\%. Artinya, Pertumbuhan Pendapatan hanya 0,3\% dipengaruhi oleh fluktuasi Margin Laba Kotor, sedangkan sisanya 99,7\% Pertumbuhan Pendapatan dipengaruhi oleh faktor lain.

Menurut Kasmir, rata-rata industri margin laba kotor suatu perusahaan adalah 30\% (Kasmir, 2010). Jika melihat pada tabel 1 margin laba kotor yang dimiliki oleh PT. ACE Hardware Indonesia, Tbk. di atas 30\%. Ini menunjukkan stabilnya harga jual dan harga pokok sehingga menghasilkan penjualan yang juga stabil. Namun, pada perusahaan yang diteliti ini margin laba bersih tidak menjadi penyumbang terbesar untuk mempengaruhi perubahan pertumbuhan pendapatan, dapat dilihat pengaruhnya hanya $0,3 \%$ dari $100 \%$. Menurut hemat peneliti pengaruh lain yang lebih besar ditimbulkan oleh rasio laba bersih, pengendalian beban yang efektif, dan penjualan yang stabil.

Merujuk pada hasil di atas, penulis mendapatkan temuan akhir bahwa pada PT. ACE Hardware Indonesia, pertumbuhan pendapatannya tidak dipengaruhi secara signifikan oleh margin laba kotor. Penelitian ini tidak mendukung penelitian sebelumnya dari (Taruh, 2012), (Utomo, 2017), (Pascarina, 2016) yang menyatakan Margin Laba Kotor berpengaruh signifikan terhadap Pertumbuhan Pendapatan.

\subsection{Pengaruh Margin Laba Operasional terhadap Pertumbuhan Pendapatan}

Thomas Sumarsan, menerangkan bahwa margin laba operasional adalah dihitung dari pengurangan penjualan bersih dan semua pengeluaran (beban), namun tidak termasuk beban 
bunga dan pajak (Sumarsan, 2013). Rasio ini berhubungan dengan operasional perusahaan artinya, rasio ini menggambarkan tingkat efisiensi dari seluruh lini seperti produksi, sumber daya manusia, penjualan dan pemasaran.

Perubahan rasio laba operasional ini disebabkan oleh berubah pula laba kotor dan berkurangnya beban operasional. Hal ini berarti, semakin meningkat margin laba operasional maka meningkat pula laba operasional yang diperoleh dari satu rupiah penjualan. Begitu pula sebaliknya, semakin menurutn laba operasional mengindikasikan rendahnya penjualan dalam menghasilkan laba operasional (Hery, 2016). Kenaikan dan penurunan ini lah yang akan mempengaruhi pertumbuhan pendapatan pada perusahaan.

Merujuk pada teori, tenyata pada penelitian ini Margin Laba Operasional tidak memiliki pengaruh terhadap terhadap Pertumbuhan Pendapatan PT. ACE Hardware Indonesia, Tbk. periode 2009-2018. Hasil penelitiannya adalah:

\section{Tabel 3 Hasil Uji Regresi Linear dan Uji $t$ Pengaruh Margin Laba Operasional terhadap Pertumbuhan Pendapatan Coefficients ${ }^{\mathrm{a}}$}

\begin{tabular}{|c|c|c|c|c|c|}
\hline \multirow[b]{2}{*}{ Model } & \multicolumn{2}{|c|}{ Unstandardized Coefficients } & $\begin{array}{c}\text { Standardized } \\
\text { Coefficients }\end{array}$ & $\mathrm{t}$ & Sig. \\
\hline & $\mathrm{B}$ & Std. Error & Beta & & \\
\hline $1 \quad$ (Constant) & -18.439 & 60.340 & & -.306 & .768 \\
\hline $\begin{array}{l}\text { Margin Laba } \\
\text { Operasional }\end{array}$ & 2.591 & 3.726 & .239 & .695 & .506 \\
\hline
\end{tabular}

a. Dependent Variable: Pertumbuhan Pendapatan

Sumber: hasil output SPSS versi 20

Berdasarkan tabel di atas diperoleh persamaan:

Pertumbuhan Pendapatan $=-18.439+2.591$ Margin Laba Operasional

Atas persamaan regresi tersebut, bisa dijelaskan apabila nilai $\mathrm{X}_{2}$ (Margin Laba Operasional) bernilai nol, maka Y (Pertumbuhan Pendapatan) bernilai -18.439. Sementara itu, jika $\mathrm{X}_{2}$ (Margin Laba Operasional) berubah sebesar 1 (satu) satuan, maka akan memberikan dampak pada peningkatan terhadap Y (Pertumbuhan Pendapatan) sebesar 2,591. Selanjutnya, persamaan regresi linear sederhana tersebut memperlihatkan bahwa Margin Laba Operasional berpengaruh positif terhadap Pertumbuhan Pendapatan.

Pengaruh Margin Laba Operasional dalam mempengaruhi kenaikan dan penurunan Pertumbuhan Pendapatan dapat dilihat dari hasil uji $t$. Dari tabel di atas interpretasinya adalah $t$ tabel sebesar 0,695 dengan signifikansi 0,506. Hal ini memenuhi syarat thitung $<t_{\text {tabel }}(0,695<$ 2,306) dengan nilai taraf signifikansi sebesar 5\%. Hasil tersebut berarti Margin Laba Operasional tidak memiliki pengaruh yang signifikan terhadap Pertumbuhan Pendapatan.

Selanjutnya kekuatan hubungan dan kontribusi pengaruh Margin Laba Operasional terhadap Penahanan Kas dapat dilihat pada tabel berikut:

Tabel 4 Hasil Uji Korelasi dan Koefisien Determinasi

\begin{tabular}{|c|c|c|c|c|}
\hline \multicolumn{5}{|c|}{ Model Summary } \\
\hline Model & $\mathrm{R}$ & R Square & Adjusted R Square & $\begin{array}{l}\text { Std. Error of the } \\
\text { Estimate }\end{array}$ \\
\hline 1 & $.239^{a}$ & .057 & -.061 & 18.28275 \\
\hline
\end{tabular}

a. Predictors: (Constant), Margin Laba Operasional

Sumber: output SPSS versi 20 
Berdasarkan perhitungan di atas dapat diketahui besarnya hubungan Margin Laba Kotor terhadap Pertumbuhan Pendapatan adalah 0,239, artinya korelasi tersebut lemah. Dan R Square $\left(\mathrm{r}^{2}\right)$ 0,057 atau sama dengan 5,7\%. Artinya, Pertumbuhan Pendapatan hanya 5,7\% dipengaruhi oleh fluktuasi Margin Laba Kotor, sedangkan sisanya 94,3\% Pertumbuhan Pendapatan dipengaruhi oleh faktor lain.

Naik turunnya margin laba operasional akan mempengaruhi profitabilitas perusahaan. Semakin tinggi permintaan konsumen terhadap produk akan berpengaruh pada produktivitas perusahaan. Oleh sebab itu perkembangan margin laba operasional akan berpengaruh pada kinerja perusahaan.Hal ini sudah dibuktikan oleh beberapa penelitian seperti penelitian (Utomo, 2017) dimana margin laba kotor tidak mempengaruhi persentase keuntungan perusahaan manufaktur. Hasil penelitian ini bertolak belakang dengan penelitian sebelumnya yang dilakukan oleh (Syamni \& Martunis, 2012), dimana margin laba operasional dan rasio pengembalian aktiva berpengaruh dan signifikan terhadap perubahan laba. Namun dalam penelitian ini tidak berlaku teori tersebut, karena menurut hemat peneliti pada PT. ACE Hardware Indonesia yang merupakan perusahaan sektor riteil peningkatan pendapatan lebih dipengaruhi oleh margin laba bersih yang tinggi, dan beban bunga yang rendah.

\subsection{Pengaruh Margin Laba Kotor dan Margin Laba Operasional terhadap Pertumbuhan Pendapatan}

Pendapatan yang terus bertumbuh atau income growth dapat dilihat dari peningkatan laba setiap periode yang dinyatakan dalam persentase. Dikatakan mengalami pertumbuhan apabila selisih antara periode sekarang dengan periode tahun sebelumnya adalah positif. Implikasinya, ketika income growth meningkat akan menjadi respon positif bagi pasar modal karena harga saham naik dan berdampak pada return saham (Gunawan \& Wahyuni, 2013). Meningkatnya persentase income growth menunjukkan perubahan kondisi keuangan perusahaan ke arah yang lebih baik.

Pertumbuhan pendapatan dipengaruhi oleh akun-akun yang ada dalam laporan keuangan perusahaan. Karena pada dasarnya, net income terbentuk dari akumulasi dan selisih dari penjualan, harga pokok penjualan, dan beban-beban operasional. Akun-akun tersebut dikonversi menjadi rasio-rasio keuangan agar dapat dianalisis, sehingga muncullah rasio laba kotor dan rasio laba operasional. Pertumbuhan pendapatan, rasio laba kotor, dan rasio laba operasional memiliki kaitan yang cukup erat, karena margin laba kotor merupakan presentase keuntungan yang diperoleh dari penjualan setiap unit produk. Sehingga kenaikan margin laba kotor akan memengaruhi pertumbuhan pendapatan yang didapatkan oleh perusahaan. Begitu pula margin laba operasional yang merupakan sisa hasil bersih kegiatan operasional perusahaan. Semakin efisien suatu perusahaan dalam memanage pengeluaran operasionalnya, maka hal tersebut akan memengaruhi pertumbuhan pendapatan perusahaan

Namun, berdasarkan hasil penelitian yang telah dilakukan tidak sesuai dengan teori di atas. Berikut hasil penelitian yang didapatkan dari pengolahan data menggunakan SPSS:

Tabel 5 Hasil Uji F

ANOVAa

\begin{tabular}{|ll|r|r|r|r|r|}
\hline Model & Sum of Squares & df & Mean Square & F & \multicolumn{1}{c|}{ Sig. } \\
\hline 1 & Regression & 473.441 & 2 & 236.721 & .701 & $.528^{\mathrm{b}}$ \\
& Residual & 2362.277 & 7 & 337.468 & & \\
& Total & 2835.718 & 9 & & & \\
\hline
\end{tabular}

a. Dependent Variable: Pertumbuhan Pendapatan

b. Predictors: (Constant), Margin Laba Operasional, Margin Laba Kotor

Sumber: hasil output SPSS versi 20 
Tabel di atas merupakan hasil uji hipotesis secara simultan, F hitung yang didapatkan adalah 0,701 dengan Sig 0,528. Ini tidak memenuhi kriteria berpengaruh, karena 0,701<4,74 dan $0,528>0,05$. Sehingga, disimpulkan secara simultan variabel margin laba kotor dan margin laba operasional tidak dapat mempengaruhi perubahan pertumbuhan pendapatan pada PT. ACE Hardware Indonesia, Tbk. periode 2009-2018.

Selanjutnya kekuatan hubungan dan kontribusi pengaruh peluang pertumbuhan dan rasio pengembalian aktiva terhadap penahanan kas dapat dilihat pada tabel berikut:

Tabel 4 Hasil Uji Korelasi dan Koefisien Determinasi

\begin{tabular}{|l|c|c|r|c|}
\hline \multicolumn{5}{|c|}{ Model Summary } \\
\hline Model & $\mathrm{R}$ & R Square & Adjusted R Square & $\begin{array}{c}\text { Std. Error of the } \\
\text { Estimate }\end{array}$ \\
\hline 1 & $.409^{a}$ & .167 & -.071 & 18.37031 \\
\hline a. Predictors: (Constant), Margin Laba Operasional, Margin Laba Kotor
\end{tabular}

Sumber: hasil output SPSS versi 20

Berdasarkan perhitungan SPSS di atas dapat diketahui besarnya hubungan margin laba kotor dan margin laba operasional terhadap pertumbuhan pendapatan adalah 0,409 berada pada interval 0,40-499 yang berarti korelasi tersebut sedang. Sedangkan, koefisien determinasi memiliki nilai 0,167 yang artinya terdapat hubungan antara margin laba kotor dan margin laba operasional terhadap pertumbuhan pendapatan sebesar $16,7 \%$ sedangkan $83,3 \%$ dipengaruhi oleh variabel lain yang tidak diteliti dalam penelitian ini.

Seperti yang telah dijelaskan sebelumnya bahwa banyak faktor yang mempengaruhi pertumbuhan pendapatan pada PT. ACE Hardware Indonesia, tbk., seperti besaran beban operasional, beban pokok penjualan, tingkat penjualan, perputaran aset, perputaran persediaan, dan rasio hutang. Jika melihat dari data yang ditampilkan pada tabel 1, dapat dilihat bahwa pertumbuhan pendapatan sangat fluktuatif, padahal margin laba kotornya sangat tinggi melebihi rata-rata industri sebesar 30\%. Rasio laba operasional juga dapat dikatakan stabil. Tetapi, kenaikan dan penurunan income growth tidak dipengaruhi oleh kedua faktor tersebut. Hasil penelitian ini mendukung penelitian sebelumnya yang dilakukan oleh Rukmono Budi Utomo yang berjudul Model Regresi Presentase Keuntungan Perusabaan Manufaktur Ditinjau dari Faktor Rasio Keuangan Berdasarkan Data ICMD.

\section{Kesimpulan}

Kesimpulan dari penelitian ini adalah secara parsial pertumbuhan pendapatan tidak dipengaruhi oleh margin laba kotor dan margin laba operasional. Dimana secara kontribusi pengaruh hanya memberikan $0,3 \%$ dan 5,7\%. Lalu, penelitian secara simultan pun juga menunjukkan hasil yang sama, bahwa margin laba kotor dan margin laba operasional tidak mampu mempengaruhi pertumbuhan pendapatan PT. ACE Hardware Indonesia, Tbk. periode 2009-2018. Secara bersamaan keduanya hanya mampu memberikan pengaruh 16,7\% pada pertumbuhan pendapatan. Ini berarti, faktor lain diluar penelitian ini pengaruhnya lebih besar dengan persentase sebesar 83,3\%. Implikasi dari penelitian ini adalah perusahaan harus memperhatikan faktor lain untuk meningkatkan pertumbuhan pendapatan, selain itu juga perusahaan harus mengontrol beban-beban operasional juga beban pokok penjualan agar maksimal menaikkan margin laba operasional dan margin laba kotor. 


\section{Referensi}

Darsono, \& Ashari. (2005). Pedoman Praktis Memahami Laporan Keuangan. Yogyakarta: Andi Offset.

Gunawan, A., \& Wahyuni. (2013). Pengaruh Rasio Keuangan terhadap Pertumbuhan Laba Pada Perusahaan Perdagangan di Indonesia. Jurnal Manajemen \& Bisnis, Vol. 13 No. 1, 63-84.

Hery. (2016). Analisis Laporan Kenangan. Jakarta: PT. Grasindo.

Kasmir. (2010). Pengantar Manajemen Keuangan. Jakarta: Kencana.

Pascarina, Y. M. (2016). Pengaruh Rasio Kenangan Terhadap Pertumbuhan Laba Pada Perusahaan Industri Penghasil Baban Baku Yang Terdaftar Di BEI Periode 2011-2013. Pekanbaru: Universitas Riau.

Samsul, M. (2015). Pasar Modal dan MAanajemen Portofolio. Bandung: Erlangga.

Subramanyam, K. R., \& Wild, J. J. (2012). Analisis Laporan Keuangan, edisi 10, buku 1. Jakarta: Salemba Empat.

Sugiyono. (2013). Metode Penelitian Kuantitatif Kualitatif dan R\&D . Bandung: Alfabeta.

Sumarsan, T. (2013). Sistem Pengandalian Manajemen Konsep, Aplikasi, dan Pengukuran Kinerja. Jakarta: PT. Index.

Syamni, G., \& Martunis. (2012). Pengaruh OPM, ROE, dan ROA Terhadap Perubahan Laba pada Perusahaan Telekomunikasi di Bursa Efek Indonesia. Jurnal Kebangsaan, Volume 2 No.4.

Syamsuddin. (2010). Manajemen Keuangan Perusabaan . Jakarta: PT. Raja Grafindo Persada.

Taruh, V. (2012). Analisis Rasio Keuangan dalam Memprediksi Pertumbuhan Laba pada Perusahaan Manufaktur di BEI. Jurnal Pelangi Ilmu, Vol. 05, No. 1.

Utomo, R. B. (2017). Model Regresi Presentase Keutungan Perusahaan Manufaktur Ditinjau dari Faktor Rasio Keuangan Berdasarkan Data ICMD. Jurnal Silogisme : Kajian Imu Matematika dan Pembelajarannya, Vol. 02, No. 1. 